\section{IE PROPER MODE OF LEARNING CHEMISTRY.}

$1 \mathrm{i}$ is worthy of notice, that whether the bject of the student be to qualify himself If a teacher of chemistry, to learn the bearhe of that science on medicine and physioIffy, or to become a manufacturer, the same arely scientific education in the art of rewarch is recommended to all. It would be Impossible, for example, to teach specially il the different chemical manufactures, so that the future iron-smelter should learn obly iron-smelting, the soap-boiler only soapboiling, \&c. ; and, if possible, it would be the reverse of beneficial. It is found by experience, that when all learn the general principles of chemistry, they acquire the special details of any manufacture in the mamufactory in a far shorter time than they could have done in the laboratory. No attempt is made, therefore, at Giessen, to teach on the small scale processes that must be practised on the large scale. The student learns practically those principles by which all chemical manufactures must be regulated, and the result may be best stated in the words of Professor Liebig himself :-

"It is generally with fear and trembling that they follow my advice, to devote their whole attention, not to imitating manufacturing processes in the laboratory, but to learning how purely scientific problems are to be resolved. They then soon and easily learn how to find the best means : they themselves modifying and shaping their means according to circunstances. Every operation, every analysis, which serves to clear up a given question, or which must be performed in order to discover the conditions essential to the resolution of the problem, has a specitic object. Each process thus acquires a certain charm that effectually wards off fatigue; and when the problem is once resolved, the student has learned the means of solving all similar problems. Many of my former pupils are now at the head of every variety of chemical manufacture. Without having ever practised these in the laboratory, they became in the first half-hour perfectly familiar with the whole process; and the next half-hour commonly produced a number of well-derised improvements in the manufacture. They had acquired in the laboratory the most exact knowledge of the properties of the materials which they had to employ, and were accustomed, as the only way of avoiding errors, to subject the products of chemical reactions to a searching investigation with regard to their composition; and they thus at once discovered the sources of error, the means of avoiding loss, and the best methods of improving the apparatus or perfecting the process. All this is not learned when the student enters a laboratory for the purpose of practising a given process by recipe."
Even for directly practical purposes, the most purely scientific education is really the best, and is more certain to lead to improvements in practice, than the most laborious experience in any one manufacture, gained, as it generally is, at the expense of general principles.-Dr. Gregory's Letter to Lord Aberdeen, p. 24.

\section{A PHYSICIAN'S CARD.}

To the Editor of THE LAncet.

SIR,-Dr. Badeley having held the office of gratuitous physician to the Chelmsford Provident Society for many years, has lately sent in his resignation, and been succeeded by a Dr. Prichard, who undertook to fulfil the duties of that office on the same terms as his predecessor; but, since his election, has injured the character of the medical profession by issuing little tea-paper circulars, with ornamental borders, such as the inclosed, in every direction :-

"Members of the Chelmsford Provident Society may obtain Dr. Prichard's attendance, and be provided with medicine upon an annual payment of $7 \mathrm{~s}$. each.

"Married members, by the payment of 3s. 6d. each per annum extra, may obtain the same privileges for their wives."

I appeal to you, Sir, as an upholder of the dignity of the profession, whether any physician is not deserving of public censure by volunteering what this circular promises; a physician, too, so truckling to the per-centage system, as to promise to provide medicine for his patients, at $7 \mathrm{~s}$. a-head, in addition to his attendance? Moreover, is it fair towards the governors of the institution to make a pretext of public charity a source of private emolument? I am, Sir, your obedient servant,

Chelmsford, March 2, 1942.

\title{
INTOXICATING PREPARATIONS.
}

\section{To the Editor of THE LanceT.}

SIR,-I much doubt creosote having the effect supposed by your correspondent "A. C."" at page 860 , having myself administered it in large doses for cutaneous diseases, without it causing symptoms of stupor or intoxication.

Whisky is a very ardent spirit, acting more quickly on the nerves than brandy, contracting all parts that it comes in contact with, and in large quantities producing either apoplexy, ending in death, palsy, delirium tremens, śc. \&c.

Can no intoxicating effects be produced by the administration of a preparation of "cocculus indicus," codine, or turpentine, in doses of one ounce? I have observed the latter produce temporary intoxication, followed by a kind of trance, which lasts for 
from twenty to thirty hours, not many ill effects on the constitution being apparent afterwards.

I think the subject of " hocussing" deserves your inquiry as a "legislator," having no doubt that many lives have been wantonly sacrificed with impunity. I am, Sir, your obedient servant,

Uxbridge, March 20, 1842.

\section{E. HuLl.}

\section{THE INCOME-TAX}

To the Editor of THE LANcer.

SIR,-From the commencement of THE Lancet I have been its reader. At no time during the existence of that work has a measure more fraught with injustice to the medical profession been broached as the proposed tax on income. I have been asked, Why should not two persons having equal incomes be equally taxed? I answer, Why should a person without capital be taxed as highly as one having $20,000 l$ ? Is a practitioner obtaining by his profession 1000l. per annum, in as good circumstances as a fundholder with the interest of $20,000 \mathrm{l}$. ?

Take two men, one with $20,000 l$, the other without money, in all other respects equal, having the same capital in head, hands, legs, and body, both with the same power of using the benefits which are equally distributed. One uses all, the other none. They ought to be equally taxed. If the lazy capital be untaxed, so ought the industrious. A professional income has a marketable value; and if industry must be taxed, the impost should be on the income which the amount of valuation may bring.

Surely the profession will not remain supine while the measure is under the consideration of Government. Every member should speak aloud, both publicly and privately, against its flagrant injustice. I am, Sir, yours, \&c.

March 17, 1842.

M.R.C.S.

\section{NORTH OF ENGLAND MEDICAL ASSOCIATION.}

\section{MEDICAL ETIQUETTE.}

At a meeting of the Council of the North of England Medical Association, held at Newcastle-upon-Tyne, March 16,1842 , Dr. Hrablam, President, in the chair,

The letter of Mr.J.B. Mavghav, relative to an alleged breach of professional etiquette, which appeared in the "Medical Gazette" of Jan. 7, The LanceT of Jan. 15, and the "Provincial Medical and Surgical Journal" of Jan. 15, 1842, was taken into consideration, and the following resolutions were adopted :-

1. That Mr. Maughan merits the approbation of the Council for the gentlemanly for- bearance with which he has conducted himself in this transaction.

2. That Dr. White was in error when he consented to inquire of the patient under the care of which surgeon she wished to remain.

3. That the conduct of Mr. Annandale, in removing the splints and bandages from a broken limb, which had been reduced by another surgeon (more especially when the immediate attendance of that surgeon was expected), was improper, and that his appropriation of the patient of another practitioner was contrary to the rules of etiquette, by which professional gentlemen should be guided in their deportment towards each other.

4. That the Council sincerely regret that the conduct of any of their professional brethren should have given occasion for the preceding resolutions: they earnestly hope that in future a better feeling will exist amongst medical men, and that similar cases will not recur.

5. That copies of these resolutions be sent to the journals in which Mr. Maughan's letter was published.

\section{MEDICAL ASSOCIATIONS.}

\section{To the Editor of THE LAnCET.}

SIr,-In your valuable Publication of Feb. 19, I observe the announcement of the formation of an association of medical men in the neighbourhood of St. George's in the East, ostensibly for the "suppression of illegal practitioners, and for the promotion of the goneral interests of the profession." I do not know any method more likely to obtain the object in view, and I trust it will be extensively followed in all parts of the United Kingdom. It is true that the contemplated Bill of Sir James Graham, should it become law, has placed the well-founded hopes of the general practitioner at zero, if not below. Still, the congregating of medical men in their several districts will produce a more general acquaintance with each other, and enable them (if it effect nothing more) to expose the insidious contrivances adopted by very many chemists and druggists for worming themselves into the houses of the rich as medical practitioners. I am, Sir, yours respectfully,

\section{March 16, 18:2.}

\section{SENEX.}

* * It should be recollected that Bethualgreen was freed from certain of its unqualified medical practitioners by advertising the names of all those persons who were visiting and prescribing for patients without possessing any medical licence, diploma, or degree. 